\title{
Risk perceptions, attitudes, and knowledge of chikungunya among the public and health professionals: a systematic review
}

\author{
Tricia Corrin ${ }^{1,2^{*}}$ (D), Lisa Waddell ${ }^{1}$, Judy Greig ${ }^{1}$, Ian Young ${ }^{3}$, Catherine Hierlihy ${ }^{1,2}$ and Mariola Mascarenhas ${ }^{1}$
}

\begin{abstract}
Background: Recently, attention to chikungunya has increased due to its spread into previously non-endemic areas. Since there is no available treatment or vaccine, most intervention strategies focus on mosquito bite prevention and mosquito control, which require community involvement to be successful. Thus, our objective was to systematically review the global primary literature on the risk perceptions, attitudes, and knowledge of chikungunya among the public and health professionals to inform future research and improve our understanding on which intervention strategies are likely to be successful.
\end{abstract}

Methods: Potentially relevant articles were identified through a standardized systematic review (SR) process consisting of the following steps: comprehensive search strategy in seven databases (Scopus, PubMed, CINAHL, CAB, LILACS, Agricola, and Cochrane) and a grey literature search of public health organizations, relevance screening, risk of bias assessment, and data extraction. Two independent reviewers performed each step. Reporting of this SR follows PRISMA reporting guidelines.

Results: Thirty-seven relevant articles were identified. The majority of the articles were published since 2011 (83.8\%) and reported on studies conducted in Asia (48.7\%) and the Indian Ocean Islands (24.3\%). The results were separated into four categories: general knowledge and perceptions on chikungunya; perceptions on the risk and severity of chikungunya; knowledge of chikungunya-harboring vectors and transmission; and knowledge, perceptions, and attitudes on mitigation practices. Overall, the systematic review found that risk perceptions, attitudes, and knowledge of chikungunya among the public and health professionals vary across populations and countries and knowledge is higher in areas that have experienced an outbreak.

Conclusion: The results suggest that most of the affected populations in this study do not understand mosquito borne diseases or chikungunya and are therefore less likely to protect themselves from mosquito bites. While more research is required to improve the generalizability of this dataset, it appears that a lack of knowledge is an important barrier for motivating community level interventions and personal protection against mosquitoes.

Keywords: Chikungunya, Systematic review, Attitudes, Knowledge, Perceptions

\footnotetext{
* Correspondence: triciacorrin@gmail.com

${ }^{1}$ Public Health Risk Sciences Division, National Microbiology Laboratory,

Public Health Agency of Canada, Guelph, ON, Canada

${ }^{2}$ Department of Population Medicine, University of Guelph, Guelph, ON,

Canada

Full list of author information is available at the end of the article
} 


\section{Background}

Chikungunya is an alphavirus that is transmitted to humans through mosquito bites. It causes a non-specific illness including high fever, severe joint pain, muscle pain, headache, nausea, fatigue, and rash in infected individuals $[1,2]$. While most people recover from the acute illness in 1-2 weeks, there are a proportion of individuals that continue to suffer from chronic joint pain which can persist for weeks to years following infection $[1,2]$.

Historically, chikungunya virus (CHIKV) has circulated in Africa, Asia, and the Indian and Pacific Ocean Islands [2]. In 2013, the virus spread to the Americas and caused outbreaks in countries that harbor the vectors, Aedes aegypti and Aedes albopictus [2-4]. Cases of infected travelers in Europe and North America returning from CHIKV-affected countries have been documented as well as several small outbreaks in Europe due to importation of the virus into an area with suitable vectors $[3,5]$.

Chikungunya is an important public health concern as the virus continues to emerge into previously nonendemic areas such as the Americas, which have reported more than 1.7 million suspected or confirmed cases since 2013 [6]. In the USA, chikungunya has been a notifiable disease since 2015, and in the same year, the Centers for Disease Control and Prevention reported 679 travel-related cases of chikungunya from 44 states [3]. Canada has reported several hundred travel-related cases of chikungunya since it spread to the Americas [7].

Most intervention strategies have focused on mosquito control and mosquito bite prevention as there is currently no treatment or vaccine for CHIKV infection in humans [8]. The success of these intervention strategies relies on social factors such as knowledge, attitudes, and perceptions of the disease. It is important to understand how affected populations understand and perceive chikungunya, its transmission cycle, and the importance of control measures to determine what prevention strategies are likely to be successful. In addition, how and why the target population chooses to take preventative action against mosquito borne diseases like CHIKV is necessary to inform future education and control strategies. Thus, a systematic review was conducted to identify, assess, and analyze the global evidence on the knowledge, attitudes, and perceptions of CHIKV and its transmission in affected populations.

\section{Methods}

\section{Research question, team, and protocol}

This systematic review was conducted following internationally recognized procedures and is reported in accordance with the PRISMA guidelines [9-11].

The systematic review question is "what are risk perceptions, attitudes and/or knowledge of chikungunya among the public and health professionals?" A multidisciplinary team with expertise in knowledge synthesis, epidemiology, risk assessment, public health, and information science conducted the review.

Prior to the systematic review, a pre-specified systematic review protocol was developed which included the research question, definitions, inclusion criteria for relevance screening, risk of bias tool, and data extraction forms. The systematic review protocol and citation list of relevant articles is available in supplementary material (Additional files 1 and 2), and the dataset resulting from this review is available upon request.

\section{Search strategy and eligibility criteria}

A scoping review of the global literature on chikungunya, conducted at the Public Health Agency of Canada (personal communication M. Mascarenhas 2017), served as the starting point for this systematic review. Briefly, the scoping review aimed to identify all relevant research on chikungunya; a search was conducted to capture all primary research in English, French, Spanish, or Portuguese. Seven electronic sources were selected based on their relevance to the scoping review. These were accessed through the Public Health Agency of Canada Library and included Scopus, PubMed, The Cumulative Index to Nursing and Allied Health Literature (CINAHL), CAB, LILACS (South America), Agricola, and the Cochrane Library for any relevant trials in the trial registry. The initial search was conducted on May 27, 2015, using a pre-tested search algorithm (Chikungunya OR CHIK OR CHIKV) OR (alphavirus AND mosquito* AND control). An updated search using the same electronic sources and algorithms was completed on January 6, 2017. A grey literature search of pre-specified public health organization $(n=19$, list available upon request) websites was undertaken to identify any non-peer-reviewed studies or surveillance data that was not captured in the electronic search. All studies on any aspect of chikungunya or CHIKV were included and characterized. One of the scoping review categories was on studies describing "Public and health professionals/physicians' knowledge, attitudes and/or risk perceptions towards chikungunya and potential prevention and control strategies." The 45 studies from this category were considered for inclusion in this systematic review. Further details on the scoping review protocol and methods are available upon request.

\section{Relevance confirmation, risk of bias assessment, and data extraction}

To ensure that the studies from the scoping review were applicable to the research question, a single relevance question appeared at the beginning of the risk of bias assessment and data extraction form to allow the reviewer to eliminate any irrelevant studies. 
All studies were evaluated for their risk of bias using a pre-designed risk of bias assessment form (Additional file 1). The form was created to address both qualitative (8 criteria) and quantitative (11 criteria) studies. Previously designed critical appraisal tools for qualitative and quantitative studies were used to create this risk of bias form [12-14]. Each study received an overall risk of bias score where studies conducted to minimize bias in the results were assigned a low risk of bias ranking. If one or more criteria could not be assessed due to lack of reporting, an unclear risk of bias was appointed. Studies received a high risk of bias if one or more criteria were not met. A data extraction form was used to extract relevant information and results from each quantitative study. The extraction form included 9 questions designed to extract information on study design, demographics, and the results of the studies that fell into the following categories: perceptions about the severity of chikungunya disease; knowledge, perceptions, and attitudes on mitigation practices; knowledge on chikungunya; and knowledge on CHIKV harboring vectors and how CHIKV is transmitted. Outcomes more generally related knowledge, perceptions, and attitudes on mosquito borne diseases (MBDs), and mosquito control reported in relevant papers on chikungunya and chikungunya-affected populations were also captured to examine if general attitudes, perceptions, and knowledge were more closely correlated to knowledge, attitudes, and perceptions on the use of personal protective measures than knowledge on chikungunya or CHIKV specifically.

Both forms were pre-tested by all team members to ensure clarity of the questions, extraction of the right information to address our research question, and to ensure process consistency. Once pre-testing was completed, two reviewers extracted the data and evaluated the risk of bias for each paper independently. During both stages, conflicts between reviewers were resolved by consensus.

\section{Review management and data analysis}

The scoping review steps, data extraction, and risk of bias assessment were conducted using the web-based systematic review software DistillerSR (Evidence Partners, Ottawa, Canada). The data was then exported to Microsoft Excel (Microsoft Corporation 2010) for descriptive analysis. Results with reference to " $n$ " refer to the total number of samples, subjects, or participants for the presented outcome.

Meta-analysis models were developed using the statistical software STATA13 (StatCorp 2015). The metaprop package was used to obtain weighted average prevalence estimates for two outcomes: the proportion of the general public sample population that were aware of chikungunya in outbreak and non-outbreak populations and the proportion of the sample population that had knowledge on mosquito transmission of CHIKV by country. Based on the assumption that the prevalence estimates would have some heterogeneity between study populations, a random effects meta-analysis was conducted using the DerSimonian and Laird method [15]. In some cases, more than one observation per study was included in the meta-analysis. We did not account for the potential similarity of these results as they were all independent observations on different sampling frames. We evaluated how much heterogeneity between studies was not explained by random error using the value $I^{2}$ [16]. High heterogeneity, $I^{2}>60 \%$, was expected, and our goal was to investigate whether there were study level variables that explained the heterogeneity and to provide a graphic of the studies for the reader. We caution readers not to use the summary estimates as an estimate of the average outcome across studies given that estimates were obtained from very different populations and no study level variables explained all the heterogeneity between studies. In the forest plots, $p=0.00$ is actually $p<0.01$. This is an output of STATA13 (StatCorp 2015) and is not open for the user to alter or redefine.

Qualitative research studies were synthesized using a narrative review approach [17]. This included two reviewers independently reviewing the results of each study and descriptively summarizing the key results as reported by the study authors. Summaries from both reviewers were discussed and consolidated to arrive at the final narrative description. Only two relevant qualitative studies were identified in this review; therefore, we decided not to use a formal coding procedure in the analysis or develop interpretive across-study themes.

\section{Results}

\section{Systematic review descriptive statistics}

There were 6820 citations screened for relevance in the scoping review project, of which 1921 studies were considered to be relevant primary research on chikungunya (Additional file 3). Only 45 of these were categorized to address knowledge, perceptions, and attitudes toward chikungunya and potential prevention and control strategies. Eight of these studies were deemed irrelevant during relevance confirmation, resulting in 37 total articles included in this systematic review. The flow of information through the systematic review process is depicted in Fig. 1.

All studies were published between 2007 and 2016, with $83.8 \%(n=37)$ published since 2011 . The majority of the articles (73.0\%) reported on studies conducted in Asia (48.7\%) and the Indian Ocean Islands (24.3\%). Specifically, most of the research originated from India (41.0\%) and La Réunion (18.0\%), as shown in Table 1 . The most widely used study design was cross-sectional (75.7\%), followed by quasi-experiment (13.5\%), qualitative (5.4\%), case-control $(2.7 \%)$, and longitudinal $(2.7 \%)$. The main population 


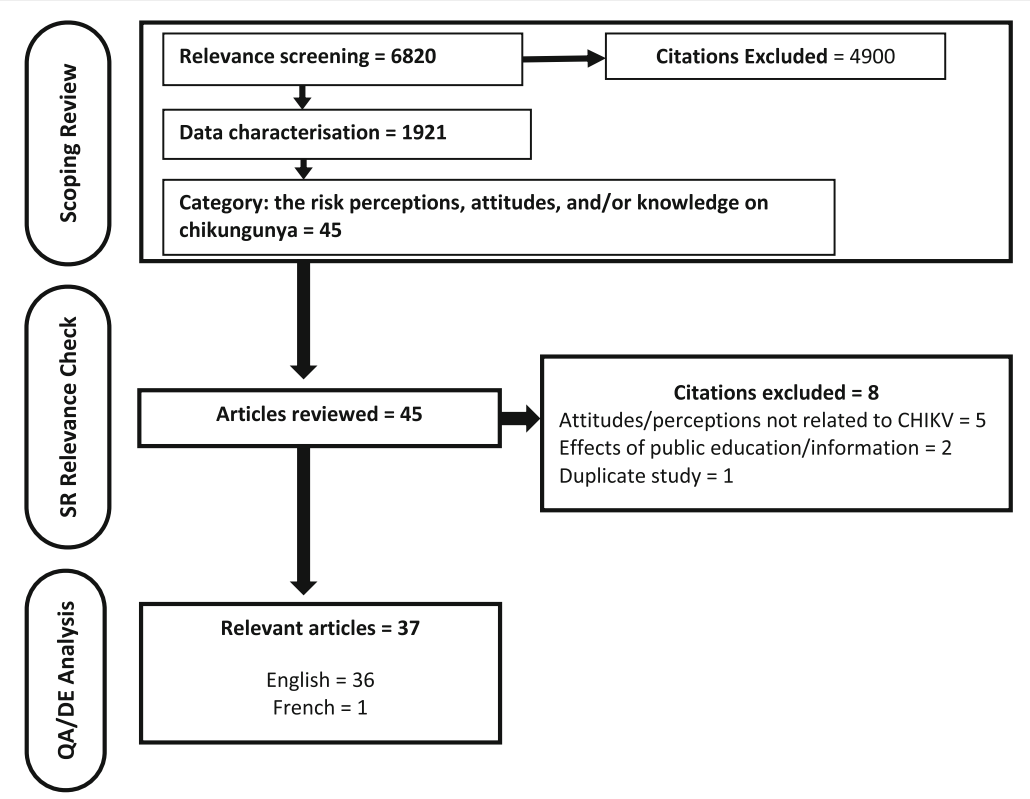

Fig. 1 PRISMA flow diagram of articles through the systematic review process

studied was the general public (86.5\%), and only a few studies had data collection processes that were informed by established theories of behavior change (24.3\%).

The 35 quantitative studies were ranked as having a low $(45.7 \%)$, unclear $(45.7 \%)$, or high $(8.6 \%)$ overall risk of bias. The most common reason for an unclear risk of bias score was due to a lack of reporting on potential confounders $(56.3 \%, n=16)$ and a lack of clarity on whether tools to measure outcomes (e.g., questionnaires) were reliably tested and validated $(81.3 \%, n=16)$. For the two qualitative studies, the main quality assessment deficiencies were that the method of analysis, research design, and data collection were not clearly described in either study.

\section{General knowledge and perceptions on chikungunya}

Awareness of chikungunya was evaluated in nine studies. Eight studies conducted in Asia $(n=7)$ and the Caribbean $(n=1)$ dichotomized results and reported awareness of chikungunya among the general public, which varied from $7-96 \%$ as shown in Fig. 2 [18-25]. The metaanalysis in Fig. 2 shows that awareness of chikungunya was highest in the four studies where an outbreak was on-going $[19,22,23]$ and among urban link workers who are responsible for implementing anti-larval measures through door-to-door visits in their community [21]. In contrast, a study conducted in Sri Lanka where an outbreak was occurring only reported an awareness rate of 7\% [24]. However, it is unclear from the study if chikungunya was an emerging disease and whether any previous public education had occurred.
Before traveling from the USA to the Dominican Republic, $19 \%$ of community service volunteers $(n=102)$ reported they had knowledge of chikungunya [26]. Of these volunteers, $87 \%(n=102)$ had visited a health-care provider for a pre-travel consultation [26]. In Nicaragua, $93.5 \%$ of individuals $(n=848)$ from a general population sample considered themselves informed about chikungunya, but actual knowledge was not evaluated [27]. Whereas in a study in India, only $8.9 \%$ of the surveyed population $(n=740)$ had correct knowledge about the virus etiology [28]. When students in French Guiana were asked about the duration of chikungunya, $51 \%(n=1462)$ answered correctly 3 weeks to several months [29].

Three studies evaluated general knowledge of mosquito borne diseases [30-32]. One of the studies attempted to gauge the level of understanding about mosquito borne diseases in the population by sampling 1506 individuals and having them rank their knowledge on a scale of $0-10$, with 0 being "do not understand at all" and 10 being "understand completely" [30]. The mean score was 5.6 (SD 2.85), indicating some knowledge, but a lack of in-depth understanding [30]. General knowledge on mosquito borne diseases in India among a group of health-care workers was $83 \%(n=100)$ [31] whereas in a different study $88.1 \%(n=119)$ [32] of the general population sample was considered to have general knowledge.

Gender was shown to be a significant predictor of knowledge of chikungunya as a mosquito borne disease in two studies from India [20,33]. In both studies, females were shown to have more knowledge about 
Table 1 General characteristics of 37 included primary research publications

\begin{tabular}{lll}
\hline Category & & Count (percentage) \\
\hline Continent/country ${ }^{\text {a,b }}$ & & \\
Asia & India & $16(41.0 \%)$ \\
& Singapore & $1(2.6 \%)$ \\
& Sri Lanka & $1(2.6 \%)$ \\
Europe & France & $2(5.1 \%)$ \\
& Italy & $1(2.6 \%)$ \\
Indian Ocean Islands & Spain & $1(2.6 \%)$ \\
& Mauritius & $7(18.0 \%)$ \\
Americas & Mayotte & $2(5.1 \%)$ \\
& USA & $2(5.1 \%)$ \\
& Colombia & $2(5.1 \%)$ \\
& French Guiana & $1(2.6 \%)$ \\
& Nicaragua & $1(2.6 \%)$ \\
& US Virgin Islands & $1(2.6 \%)$ \\
&
\end{tabular}

Language

$\begin{array}{ll}\text { English } & 36(97.3 \%) \\ \text { French } & 1(2.7 \%)\end{array}$

Date of publication

$\begin{array}{ll}2007-2010 & 6(16.2 \%) \\ 2011-2016 & 31(83.8 \%)\end{array}$

Risk of bias assessment ${ }^{c}$

$\begin{array}{ll}\text { Low risk of bias } & 16(45.7 \%) \\ \text { Unclear risk of bias } & 16(45.7 \%) \\ \text { High risk of bias } & 3(8.6 \%)\end{array}$

Study design

$\begin{array}{ll}\text { Cross-sectional } & 28(75.7 \%) \\ \text { Quasi-experiment } & 5(13.5 \%) \\ \text { Qualitative } & 2(5.4 \%) \\ \text { Case-control } & 1(2.7 \%) \\ \text { Longitudinal } & 1(2.7 \%)\end{array}$

Population

$\begin{array}{ll}\text { General public } & 32(86.5 \%) \\ \text { Health professionals } & 5(13.5 \%)\end{array}$

Theory of behavior change used

$\begin{array}{ll}\text { None } & 28(75.7 \%) \\ \text { Health belief model } & 3(8.1 \%) \\ \text { Stages of change theory } & 2(5.4 \%) \\ \text { Theory of planned behavior } & 4(10.8 \%)\end{array}$

${ }^{\text {a }}$ Total number sums to $>37$ as studies can fall into more than one category ${ }^{b}$ Total percentages do not equal 100 due to rounding

'Total number sums to 35 as qualitative studies were not given an overall risk of bias score mosquito borne disease $(13.8 \%, n=350)$ compared to males $(4.8 \%, n=350), p$ value 0.01 [20] and chikungunya (OR 1.37; 95\% CI 1.11-1.71; $p=0.003 ; n=1674$ ) [33]. Other significant socio-economic factors included less knowledge among illiterate participants (OR 0.65; 95\% CI: $0.51-0.82) ; p<0.001)$ and participants over the age of 30 (OR 0.67; 95\% CI: $0.54-0.83 ; p<0.01$ ) compared to those that were literate or between the age of 18-30 [33].

Eight studies measured knowledge of chikungunya $[22,30,31,34,35]$ and mosquito borne disease [29, $36,37]$ symptoms among populations affected by the disease. Knowledge of the signs and symptoms of chikungunya varied across different study populations; however, joint pain, fever, and swelling were commonly identified [22, 30, 35]. In a group of healthcare workers in India, 22\% $(n=100)$ had knowledge on chikungunya symptoms [31]. The results of a case-control study where the cases were diagnosed with chikungunya showed that those with first-hand experience of the disease were more aware of the symptoms of the disease in comparison with the noncases [35]. In a study of health-care workers and medical students in two Colombian cities, participants correctly identified polyarthralgia and fever as the most frequent symptoms of chikungunya: $91.9 \%$ in Pereira $(n=99)$ and $86.9 \%$ in Cartagena $(n=107)$ [34]. For mosquito borne diseases, the most frequently reported symptoms included limb swelling, fever, headache, myalgia, arthralgia, and skin rashes $[29,36]$. In one study, knowledge about the symptoms of mosquito borne disease varied depending on whether larval breeding sites were identified around the home [37]. In the absence of larval breeding sites on an individual's property, 37.5\% surveyed $(n=160)$ had no knowledge of the symptoms of mosquito borne diseases compared to $62.5 \%$ of individuals where larval breeding sites were identified on their property [37]. Larval breeding sites around homes was used as a surrogate measure for risk of exposure, and knowledge of symptoms is presumably due to personal experience with someone in the home being ill from CHIKV.

Perceptions on the treatment of chikungunya were addressed in four studies, two of which sampled populations of health professionals [26, 30, 38, 39]. A group of final year medical students $(n=314)$ from Singapore were surveyed and $20.1 \%$ believed that it is necessary to isolate patients who have chikungunya [38]. Five doctors $(100 \%)$ surveyed in India believed that the traditional system of medicine called Ayurveda was more effective than other systems of medicine to treat chikungunya [39]. In addition, these same doctors all believed that homeopathic medicine can cure chikungunya completely, but only $60 \%$ were aware of the efficacy and adverse effects of the treatment used [39]. In France, 1506 participants from the general public gave a mean score of 7.01 


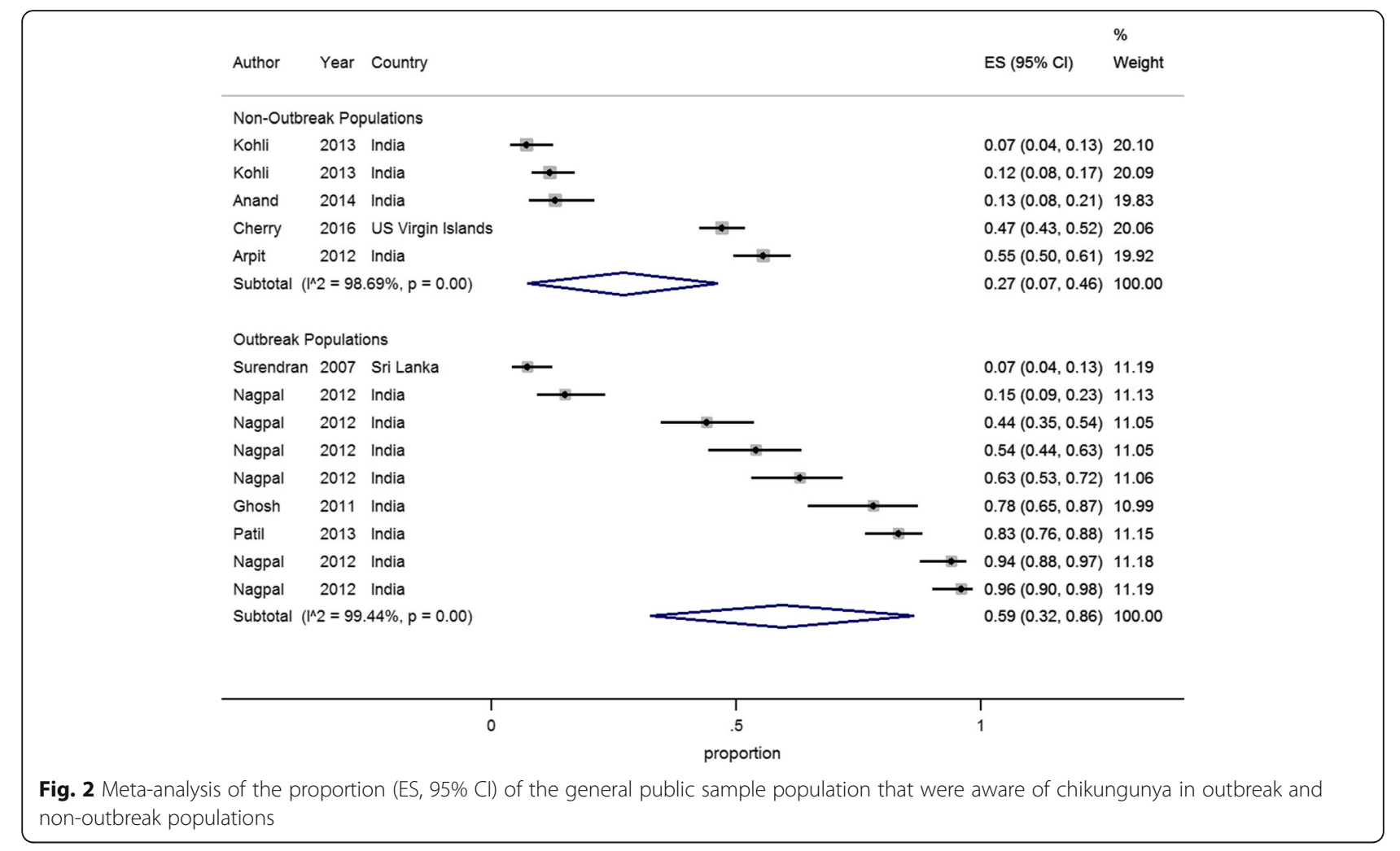

(SD 2.24) out of 10 that treatment can help with mosquito borne diseases including chikungunya, where 0 indicates no effect of treatment and 10 indicates treatment is highly effective [30]. From a group of community service volunteers in the USA with knowledge on chikungunya, $68 \%$ $(n=19)$ believed there was no available treatment for the disease [26].

\section{Perceptions on the risk and severity of chikungunya}

Six studies looked at perceptions of the risk and severity of chikungunya among populations of the general public that were recently affected by an outbreak (Table 2) [26, 29, 40-43]. The perceived severity of the disease was deemed to be high or moderate by 20.5 $93.4 \%$ of the participants across three studies $(n=1021$, $n=880)$ conducted on the Indian Ocean Islands $[41,43]$ and $94.5 \%(n=18)$ in a group of USA community volunteers traveling to the Dominican Republic [26]. Following a small CHIKV outbreak in Italy, $49.8 \%(n=293)$ of the population in the affected region perceived a high risk associated with chikungunya, and $83.2 \%(n=291)$ were worried about the disease in the near future [40]. Whereas a study conducted in France $(n=1506)$ reported that the perceived severity of mosquito borne diseases was moderate, mean score of 7.07 (SD 1.94), and they were less concerned about the risk of contracting a mosquito borne disease, mean score 4.89 (SD 3.15), which may be because many mosquito borne diseases are not endemic in France
[30]. Another study conducted in the USA reported that $63 \%$ of the surveyed population $(n=87)$ were a little or very worried about contracting a mosquito borne disease such as chikungunya or dengue, but only $15 \%(n=88)$ believed it was likely that someone they knew would contract a mosquito borne disease [44].

\section{Knowledge of chikungunya-harboring vectors and transmission}

Twenty-four studies assessed what proportion of a study population knew that CHIKV is transmitted to humans through mosquito bites [19, 22-30, 32-36, 40-42, 45-50]. All of these studies looked at the general population with the exception of one study that looked at a group of health professionals in Colombia. The results of the metaanalysis in Fig. 3 indicate that knowledge levels on transmission of CHIKV by mosquitoes range widely between 2 and $97 \%$ across studies.

A few studies of the general public conducted on the Indian Ocean Islands found that there are misconceptions on how and why CHIKV is transmitted. One study $(n=1035)$ reported $73.3 \%(n=989)$ of participants were aware that mosquitoes transmit CHIKV; however, participants also believed that CHIKV could be transmitted through the air $(36.5 \%, n=996)$ and/or direct human contact $(33.9 \%, n=999)$ [41]. When asked how CHIKV was introduced to the island, responses varied from the bodies of tsunami victims that reached the island (33.1\%, 
Table 2 Perceived risk and severity of chikungunya and mosquito borne diseases (MBDs) among the general public

\begin{tabular}{|c|c|c|c|c|c|}
\hline REF & Author (year) & Location & Sample size & Proportion or mean score & Description of outcome \\
\hline \multicolumn{6}{|c|}{ Chikungunya } \\
\hline [29] & Fritzell (2016) & French Guiana & 1462 & $\begin{array}{l}\text { Mean score }=5.37 \\
95 \% \text { Cl: } 5.12-5.63\end{array}$ & Perceived risk of exposure to chikungunya \\
\hline [40] & Moro (2010) & Italy & 293 & $49.8 \%$ & Perceived a high risk associated with chikungunya \\
\hline [40] & Moro (2010) & Italy & 291 & $83.2 \%$ & Worried about chikungunya in the near future \\
\hline [41] & Setbon (2008) & La Réunion & 1021 & $\begin{array}{l}\text { 2.7\% (score: } 0-3 \text { ) } \\
\text { 20.5\% (score: } 4-6) \\
76.8 \% \text { (score: } 7-10)\end{array}$ & $\begin{array}{l}\text { Perceived severity of chikungunya on a scale of } \\
0-10(0-\text { low }, 10-\text { high })\end{array}$ \\
\hline [42] & Thuilliez (2014) & La Réunion & 1024 & $47.7 \%$ & $\begin{array}{l}\text { Perceived risk of a new chikungunya outbreak } \\
\text { was reasonable or high }\end{array}$ \\
\hline [43] & Raude (2009) & Mayotte & 880 & $\begin{array}{l}93.4 \% \text { (high or moderate) } \\
6.6 \% \text { (low or none) }\end{array}$ & Perceived severity of chikungunya \\
\hline [26] & Millman (2016) & USA & 18 & $94.5 \%$ & $\begin{array}{l}\text { Perceived possible risk of exposure in Dominican } \\
\text { Republic }\end{array}$ \\
\hline \multicolumn{6}{|c|}{ Mosquito borne diseases (MBD) } \\
\hline [30] & Raude (2012) & France & 1506 & $\begin{array}{l}\text { Mean score }=7.07 \\
\mathrm{SD}=1.94\end{array}$ & $\begin{array}{l}\text { Perception on how serious MBDs are on a scale of } \\
0-10 \text { ( } 0 \text { - not serious, } 10 \text { - serious) }\end{array}$ \\
\hline [30] & Raude (2012) & France & 1506 & $\begin{array}{l}\text { Mean score }=4.89 \\
\mathrm{SD}=3.15\end{array}$ & $\begin{array}{l}\text { Worried about the risk of contracting MBDs on a } \\
\text { scale of } 0-10(0-\text { not worried at all, } 10- \\
\text { extremely worried) }\end{array}$ \\
\hline [33] & Boratne (2010) & India & 1674 & $54.9 \%$ & $\begin{array}{l}\text { Perceived MBDs as a serious problem in the area } \\
(54.9 \%)\end{array}$ \\
\hline [24] & Surendran (2007) & Sri Lanka & 162 & $\begin{array}{l}\text { 29\% (severe) } \\
71 \% \text { (moderate) }\end{array}$ & Perception of the mosquito problem \\
\hline [61] & Boyer (2014) & La Réunion & Not reported & $78.9 \%$ & Good knowledge of vectorial risk \\
\hline [25] & Cherry (2016) & US Virgin Islands & 443 & $\begin{array}{l}\text { 43\% (not concerned) } \\
49.5 \% \text { (mildly concerned) } \\
7.5 \% \text { (very concerned) }\end{array}$ & Concerned about getting a MBD during their trip \\
\hline [44] & Adalja (2016) & USA & 87 & $\begin{array}{l}37 \% \text { (had not thought about } \\
\text { it or were not worried at all) } \\
63 \% \text { (a little worried or } \\
\text { very worried) }\end{array}$ & $\begin{array}{l}\text { Level of worry about MBDs like dengue or } \\
\text { chikungunya }\end{array}$ \\
\hline [44] & Adalja (2016) & USA & 88 & $\begin{array}{l}85 \% \text { (very unlikely, unlikely, } \\
\text { or uncertain) } \\
15 \% \text { (likely or very likely) }\end{array}$ & $\begin{array}{l}\text { Perceived likelihood that someone they know } \\
\text { could contract dengue or chikungunya while } \\
\text { living in their community }\end{array}$ \\
\hline
\end{tabular}

$M B D$ mosquito borne disease, $S D$ Standard deviation, $95 \% \mathrm{Cl}=95 \%$ confidence interval

$n=983)$, crews of quarantined ships $(61.7 \%, n=981)$ to intentional introduction by secret agents $(26.8 \%$, $n=965)$ [41]. A large proportion of a population in Mayotte $(n=888)$ believed that the proximate cause of CHIKV is mosquitoes $(77 \%, n=835)$, but the ultimate cause is God's punishment $(55.4 \%, n=802)$, migrants (36.8\%, $n=742)$, and witchcraft/sorcery $(12.5 \%, n=807)$ [43]. This same group of participants $(n=888)$ also believed the virus can be transmitted by blood transfusion (64\%), sexual intercourse (40\%), animals (30\%), and by shaking the hand of an infected person (21\%) [48].

Knowledge of the general public on mosquito breeding sites was assessed in ten studies $[18,20,23,31-33,35$, $36,45,51]$. With the exception of one study from Spain, all were conducted in India. Between 2008 and 2010, $84.9 \%$ of a studied population in Spain $(n=820) \mathrm{knew}$ about the larval habitats of tiger mosquitoes [51]. In
India, $89 \%$ of a surveyed group of health-care workers $(n=100)$ had knowledge of mosquito breeding sites [31]. Across all studies (Table 3), stagnant water (29-85\%) $[18,20,23,33,36]$ and coconut shells $(4.2-73 \%)[20,33$, 35,45 ] were most commonly identified as places where mosquitoes breed. Other breeding places such as cement baths [35], vehicle tires [20, 33], water storage jars [35], broken utensils [45], cracks in the wall, drain and polluted water [32], and desert coolers [20] were cited with lower frequency. Those with first-hand experience of the disease in a case-control study conducted in India were found to have less knowledge on mosquito breeding sites than those who were selected as non-cases [35]. For example, $73 \%$ of individuals who did not have the disease $(n=450)$ knew that mosquitoes breed in coconut shells as opposed to $35 \%$ of those who had contracted chikungunya $(n=150)$ [35]. 


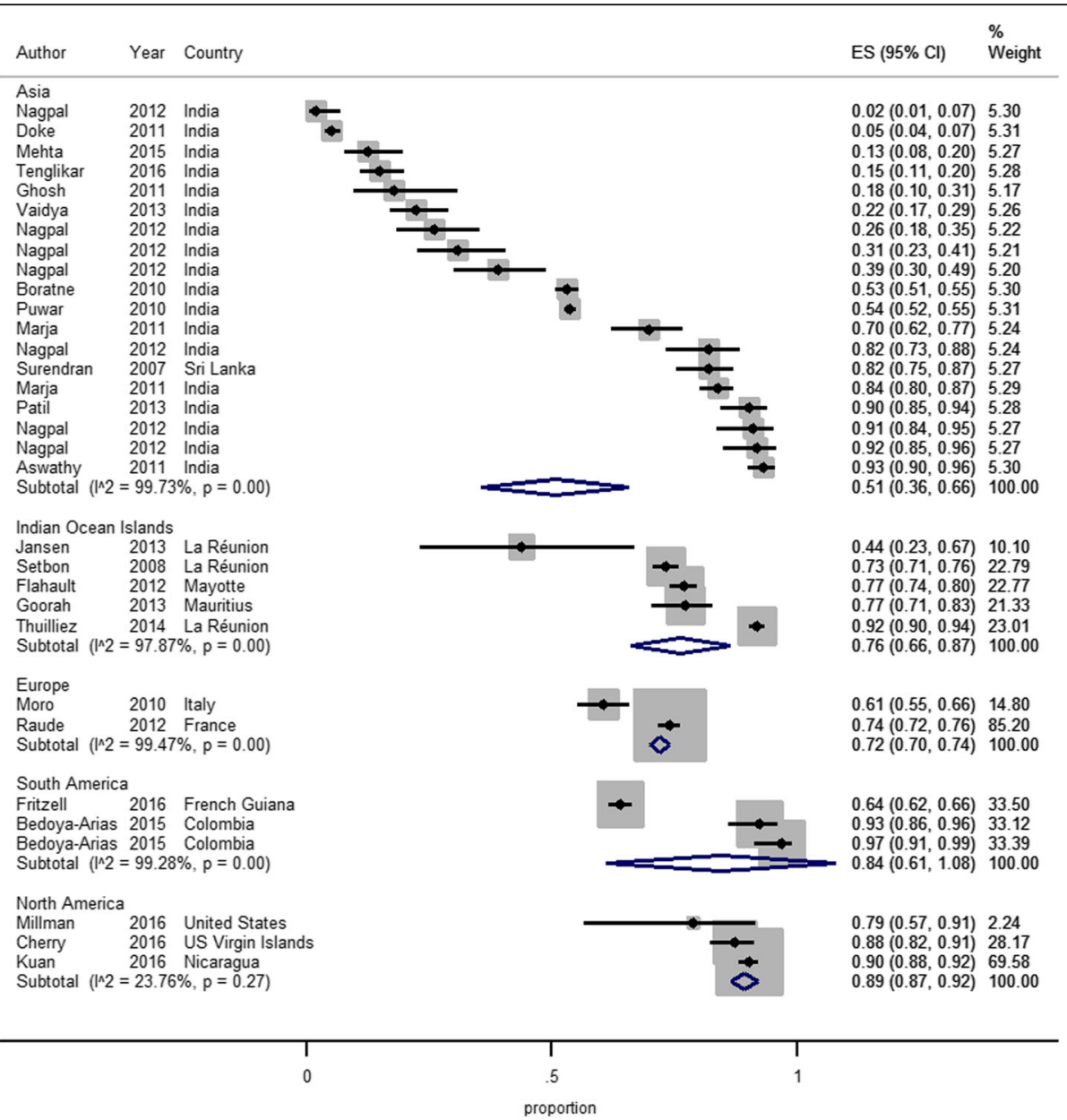

Fig. 3 Meta-analysis of the proportion (ES, 95\% Cl) of the sample population that had knowledge on mosquito transmission of CHIKV by country

\section{Knowledge, perceptions, and attitudes on mitigation practices}

The perception of personal control or "self-responsibility" for mitigation of CHIKV varied among four studies of the general public. In a study conducted in India, $42.7 \%$ of participants $(n=178)$ believed that they were personally responsible for the mitigation of CHIKV [46]. On the Indian Ocean Islands where a large chikungunya outbreak was occurring for the first time, 54\% $(n=1021)$ [41] did not believe they had any control over the disease whereas another study on the island reported that $83.9 \%(n=888)$ [43] believed that chikungunya is controllable. In France, participants indicated they have a moderate level of control over their risk of contracting mosquito borne diseases, mean 7.12 (SD 2.39) on a scale of $0-10$, with 0 having absolutely no control and 10 having an extreme amount of control [30].

Knowledge on government measures for the prevention and control of mosquito borne diseases varied across three studies conducted in India, 21.1\% $(n=1674), 84 \%$ $(n=100)$, and $88.9 \%(n=135)[18,32,33]$. Following an outbreak in La Réunion, 55\% ( $n=999)$ of the study participants from the general public believed that public authorities had done everything in their power to stop the spread of chikungunya [41]. However, during the same outbreak, the management directives from health authorities in La Réunion were perceived as ineffective by $60.4 \%(n=91)$ of health professionals [52]. Variation on the perceived effectiveness of mitigation measures was also seen between studies of the general public. The perceived effectiveness of CHIKV protective measures was positive in Mayotte $(79.7 \%, n=888)$ and La Réunion $(64.8 \%, n=1024)$ [42, 43], but in India, only $14 \%(n=84)$ and $28.3 \%$ $(n=120)$ of participants from two studies believed the protective measures to be adequate $[18,32]$. The participants from one of the studies in India cited corruption, a late reactive approach, and a lack of accountability in the system as reasons for the inadequacy and ineffective mitigation [18].

Thirteen studies [18-23, 31-33, 35, 43, 45, 46] captured knowledge of the general public on vector control and personal protective measures. The majority (92.3\%, 
Table 3 General public's knowledge on mosquito breeding sites

\begin{tabular}{|c|c|c|c|c|}
\hline REF & Author (year) & Location & Sample size & Results \\
\hline \multicolumn{5}{|c|}{ Stagnant water } \\
\hline [18] & Anand (2014) & India & 100 & Stagnant polluted water (29\%), stagnant clean water (68\%) \\
\hline [33] & Boratne (2010) & India & 1674 & Stagnant water $(60.7 \%)$, ditches $(35 \%)$, ponds $(24 \%)$ \\
\hline [20] & Kohli (2013) & India & 350 & Stagnant water (60.9\%), blocked drains (40\%) \\
\hline [23] & Ghosh (2011) & India & 50 & Stagnant water (66\%) \\
\hline [36] & Tenglikar (2016) & India & 247 & Dirty stagnant water (85\%) \\
\hline [32] & Mehta (2015) & India & 119 & Drain and polluted water (58.8\%) \\
\hline \multicolumn{5}{|c|}{ Water - storage and other } \\
\hline [35] & Majra (2011) & India & 150 cases, 450 non-cases & Water storage jars—cases (48\%), non-cases (66\%) \\
\hline [32] & Mehta (2015) & India & 119 & Clean water collection (27.7\%) \\
\hline [36] & Tenglikar (2016) & India & 247 & Artificial collection of water/water storage (14.6\%) \\
\hline \multicolumn{5}{|c|}{ Small containers } \\
\hline [18] & Anand (2014) & India & 100 & Desert coolers (20\%) \\
\hline [45] & Aswathy (2011) & India & 300 & Coconut shells and broken utensils (69\%) \\
\hline [33] & Boratne (2010) & India & 1674 & Vehicle tires (2.6\%); coconut shells (4.2\%) \\
\hline [20] & Kohli (2013) & India & 350 & $\begin{array}{l}\text { Old tires, broken pots and coconut shells (41.4\%), } \\
\text { desert coolers (26.3\%) }\end{array}$ \\
\hline [35] & Majra (2011) & India & 150 cases, 450 non-cases & $\begin{array}{l}\text { Coconut shells_cases (35\%), non-cases (73\%), tires_cases } \\
(13 \%), \text { non-cases }(54 \%)\end{array}$ \\
\hline \multicolumn{5}{|l|}{ Other } \\
\hline [23] & Ghosh (2011) & India & 50 & Cracks in walls (2\%), earth and air (2\%) \\
\hline [35] & Majra (2011) & India & 150 cases, 450 non-cases & Cement baths—cases (28\%), non-cases (66\%) \\
\hline
\end{tabular}

$n=13$ ) of these studies were conducted in India. Table 4 shows many differences between knowledge of various protective measures across studies. Knowledge on the vector control measures using larvicides $(0.8-79.2 \%)[19,31$, 35 ] and biological measures (2.9-54.7\%) [21, 23, 33] were the least known control measures. Whereas knowledge on using insecticides (5-83.2\%) [19, 21, 22, 31, 32, 35] and "chemicals" (34-79.2\%) [21, 32, 33], which is likely synonymous with insecticides were widely understood mosquito control measures.

Studies reported a large range in knowledge of personal protective measures (PPMs) (Table 5). Knowledge of the general public and health-care workers on the use of mosquito repellents and bed nets ranged from 0 to $92 \%$ in five studies from India $[19,21,22,32,35]$, while knowledge of wearing protective clothing ranged (1-30\%) across two studies from India [22, 45].

When a group of 1462 students in Nicaragua were surveyed about the effectiveness of several preventative measures against mosquito bites, the most commonly reported measures were bed nets (60.6\%), sprays $(60.5 \%)$, window nets $(58.6 \%)$, and the removal of stagnant water from containers (58.5\%) [29]. Wearing protective clothing (35\%) and closing windows (33\%) were perceived by this group to be less effective at reducing mosquito bites [29].
Knowledge on the availability of a vaccine for chikungunya was assessed in two studies $[26,29]$. In a group of students from French Guiana $(n=1462), 16 \%$ believed there was a vaccine for chikungunya [29]. Of the community service volunteers from the USA traveling to the Dominican Republic who had self-reported pre-travel knowledge on chikungunya, 67\% $(n=19)$ correctly answered there is no vaccine available for chikungunya [26]. A community opinion survey on the use of genetically modified mosquitoes as a method of mosquito management was conducted in the USA [44]. This novel approach to mosquito control was opposed by $58 \%$ of the respondents $(n=86)$ and the remaining $42 \%$ were either neutral or supported the method [44]. When multiple vector control measures were ranked on a scale of 1-5 ( 1 being the method they support the most and 5 the least), this group was most supportive of draining water on private property to reduce mosquito breeding (mean $=1.98)$ and least supportive of genetically modified mosquitoes to reduce the mosquito population $($ mean $=4.14)[44]$.

\section{Qualitative studies}

Two qualitative research articles were identified from the same author [50,53], both focusing on local experiences and responses to the 2005-2007 chikungunya epidemic in 
Table 4 Knowledge of the general public on vector control

\begin{tabular}{|c|c|c|c|c|c|c|}
\hline & Author (year) & Location & Sample size & Proportion & Preventative measure & Description of outcome \\
\hline \multicolumn{7}{|c|}{ Source reduction of mosquito breeding areas } \\
\hline [18] & Anand (2014) & India & 100 & $47 \%$ & Source reduction & Knowledge on prevention of MBDs \\
\hline [19] & Patil (2013) & India & 154 & $12.5 \%$ & Source reduction & $\begin{array}{l}\text { Knowledge on preventing } \\
\text { chikungunya }\end{array}$ \\
\hline [22] & Nagpal (2012) & India & 1000 & $\begin{array}{l}4-69 \% \text { across } \\
\text { study states }\end{array}$ & Source reduction & $\begin{array}{l}\text { Knowledge on how to eliminate } \\
\text { mosquito breeding }\end{array}$ \\
\hline [45] & Aswathy (2011) & India & 300 & $39 \%$ & Environmental sanitation & $\begin{array}{l}\text { Knowledge of the means to } \\
\text { prevent mosquito breeding }\end{array}$ \\
\hline [33] & Boratne (2010) & India & 1674 & $20.8 \%$ & Environmental & $\begin{array}{l}\text { Knowledge on vector control } \\
\text { measures }\end{array}$ \\
\hline [21] & Arpit (2012) & India & 274 & $34.7 \%$ & Environmental & $\begin{array}{l}\text { Knowledge on mosquito control } \\
\text { measures }\end{array}$ \\
\hline [20] & Kohli (2013) & India & 350 & $49.7 \%$ & $\begin{array}{l}\text { Prevent stagnation of } \\
\text { water }\end{array}$ & Knowledge on prevention of MBDs \\
\hline [31] & Thakor (2015) & India & 100 & $34.7 \%$ & Environmental & $\begin{array}{l}\text { Knowledge on vector control } \\
\text { measures }\end{array}$ \\
\hline [32] & Mehta (2015) & India & 120 & $31.6 \%$ & Regular cleaning of drainage & $\begin{array}{l}\text { Knowledge of government } \\
\text { measures to prevent MBDs }\end{array}$ \\
\hline [32] & Mehta (2015) & India & 103 & $66 \%$ & $\begin{array}{l}\text { Keeping surroundings clean } \\
\text { and proper drainage }\end{array}$ & Knowledge on prevention of MBDs \\
\hline \multicolumn{7}{|c|}{ Source reduction from drinking water containers } \\
\hline [18] & Anand (2014) & India & 100 & $20 \%$ & $\begin{array}{l}\text { Draining water and cleaning } \\
\text { coolers }\end{array}$ & Knowledge on prevention of MBDs \\
\hline [45] & Aswathy (2011) & India & 300 & $20.7 \%$ & $\begin{array}{l}\text { Overturning plastic cups, } \\
\text { containers, and other } \\
\text { receptacles }\end{array}$ & $\begin{array}{l}\text { Knowledge of measures to } \\
\text { prevent mosquito breeding }\end{array}$ \\
\hline [20] & Kohli (2013) & India & 350 & $41.1 \%$ & Cover water containers & Knowledge on prevention of MBDs \\
\hline [20] & Kohli (2013) & India & 350 & $21.1 \%$ & Cleaning of coolers & Knowledge on prevention of MBDs \\
\hline [35] & Majra (2011) & India & $\begin{array}{l}150 \text { cases, } 450 \\
\text { non-cases }\end{array}$ & $\begin{array}{l}36 \% \text { cases } \\
64 \% \text { non-cases }\end{array}$ & $\begin{array}{l}\text { Changing stored water } \\
\text { frequently }\end{array}$ & $\begin{array}{l}\text { Knowledge on preventative } \\
\text { measures }\end{array}$ \\
\hline [35] & Majra (2011) & India & $\begin{array}{l}150 \text { cases, } 450 \\
\text { non-cases }\end{array}$ & $\begin{array}{l}40 \% \text { cases } \\
68 \% \text { non-cases }\end{array}$ & $\begin{array}{l}\text { Turning containers upside } \\
\text { down }\end{array}$ & $\begin{array}{l}\text { Knowledge on preventative } \\
\text { measures }\end{array}$ \\
\hline \multicolumn{7}{|c|}{ Biological } \\
\hline [33] & Boratne (2010) & India & 1674 & $2.9 \%$ & Biological & $\begin{array}{l}\text { Knowledge on vector control } \\
\text { measures }\end{array}$ \\
\hline [23] & Ghosh (2011) & India & 50 & $8 \%$ & Fish & Knowledge on mosquito control \\
\hline [21] & Arpit (2012) & India & 274 & $54.7 \%$ & Biological & $\begin{array}{l}\text { Knowledge on mosquito control } \\
\text { measures }\end{array}$ \\
\hline [31] & Thakor (2015) & India & 100 & $54.7 \%$ & Biological & $\begin{array}{l}\text { Knowledge on vector control } \\
\text { measures }\end{array}$ \\
\hline \multicolumn{7}{|c|}{ Larvicides } \\
\hline [19] & Patil (2013) & India & 154 & $0.8 \%$ & Larvicides & $\begin{array}{l}\text { Knowledge on preventing } \\
\text { chikungunya }\end{array}$ \\
\hline [35] & Majra (2011) & India & $\begin{array}{l}150 \text { cases, } 450 \\
\text { non-cases }\end{array}$ & $\begin{array}{l}4 \% \text { cases } \\
10 \% \text { non-cases }\end{array}$ & Using abate & $\begin{array}{l}\text { Knowledge on preventative } \\
\text { measures }\end{array}$ \\
\hline [31] & Thakor (2015) & India & 100 & $79.2 \%$ & Anti-larval method & $\begin{array}{l}\text { Knowledge on vector control } \\
\text { measures }\end{array}$ \\
\hline \multicolumn{7}{|c|}{ Insecticides } \\
\hline [19] & Patil (2013) & India & 154 & $33.1 \%$ & Insecticide spraying & $\begin{array}{l}\text { Knowledge on preventing } \\
\text { chikungunya }\end{array}$ \\
\hline [22] & Nagpal (2012) & India & 1000 & $\begin{array}{l}5-48 \% \text { across } \\
\text { study States }\end{array}$ & Treatment with insecticides & $\begin{array}{l}\text { Knowledge on how to eliminate } \\
\text { mosquito breeding }\end{array}$ \\
\hline
\end{tabular}


Table 4 Knowledge of the general public on vector control (Continued)

\begin{tabular}{|c|c|c|c|c|c|c|}
\hline$[35]$ & Majra (2011) & India & $\begin{array}{l}150 \text { cases, } 450 \\
\text { non-cases }\end{array}$ & $\begin{array}{l}64 \% \text { cases } \\
68 \% \text { non-cases }\end{array}$ & Spraying insecticides & $\begin{array}{l}\text { Knowledge on preventative } \\
\text { measures }\end{array}$ \\
\hline [21] & Arpit (2012) & India & 274 & $83.2 \%$ & Space spray & $\begin{array}{l}\text { Knowledge on mosquito control } \\
\text { measures }\end{array}$ \\
\hline [31] & Thakor (2015) & India & 100 & $83.2 \%$ & Space spray & $\begin{array}{l}\text { Knowledge on vector control } \\
\text { measures }\end{array}$ \\
\hline [32] & Mehta (2015) & India & 120 & $34.2 \%$ & Spraying and fogging & $\begin{array}{l}\text { Knowledge of government } \\
\text { measures to prevent MBDs }\end{array}$ \\
\hline \multicolumn{7}{|c|}{ Unspecified Chemical } \\
\hline [33] & Boratne (2010) & India & 1674 & $61.1 \%$ & Chemical & $\begin{array}{l}\text { Knowledge on vector control } \\
\text { measures }\end{array}$ \\
\hline [21] & Arpit (2012) & India & 274 & $79.2 \%$ & Chemical & $\begin{array}{l}\text { Knowledge on mosquito control } \\
\text { measures }\end{array}$ \\
\hline [32] & Mehta (2015) & India & 103 & $34 \%$ & $\begin{array}{l}\text { Spraying chemicals on } \\
\text { water and keeping the } \\
\text { surrounding clean }\end{array}$ & Knowledge on prevention of MBDs \\
\hline [32] & Mehta (2015) & India & 120 & $34.2 \%$ & $\begin{array}{l}\text { Chemical spraying and } \\
\text { cleaning of garbage }\end{array}$ & $\begin{array}{l}\text { Knowledge of government } \\
\text { measures to prevent MBDs }\end{array}$ \\
\hline \multicolumn{7}{|l|}{ Other } \\
\hline [43] & Raude (2009) & Mayotte & 888 & $59.2 \%$ & Vector control & Knowledge of vector control \\
\hline [33] & Boratne (2010) & India & 1674 & $0.6 \%$ & Integrated & $\begin{array}{l}\text { Knowledge on vector control } \\
\text { measures }\end{array}$ \\
\hline [20] & Kohli (2013) & India & 350 & $\begin{array}{l}38.6 \% \\
12 \%\end{array}$ & $\begin{array}{l}\text { Cleaning up garbage } \\
\text { Putting kerosene oil in } \\
\text { coolers }\end{array}$ & Knowledge on prevention of MBDs \\
\hline [21] & Arpit (2012) & India & 274 & $4 \%$ & Genetic method & $\begin{array}{l}\text { Knowledge on mosquito control } \\
\text { measures }\end{array}$ \\
\hline
\end{tabular}

$M B D$ mosquito borne disease

La Réunion. The first article reported on an anthropological study consisting of interviews with 16 residents who believed they had been ill with the disease [53]. Participants had differing beliefs regarding the etiology of chikungunya, with seven participants leaning toward biomedical explanations of CHIKV as vector-borne, while others thought that the infection was air-borne or due to poor sanitary conditions [53].

"Although bann la [they, all of them] said that chikungunya is a mosquito, I don't think so because mosquitoes have always existed here in Réunion" (quote from participant, reported in Jansen, 2012).

The second study reported on a discourse analysis of 111 local newspaper articles published in La Réunion during the chikungunya epidemic [50]. These newspapers functioned as a secondary source to communicate local perceptions and experiences with the epidemic [50]. The analysis revealed that coverage of the epidemic began as informational, but became increasingly political at the height of the epidemic, with criticisms of the government's response [50]. For instance, many Réunionese did not believe that chikungunya was transmitted by mosquitoes, but rather that the state was keeping important information from them [50].

\section{Discussion}

Risk perceptions, attitudes, and knowledge of chikungunya among the public and health professionals vary across populations and countries as shown in this systematic review. The results suggest that the majority of the populations in the captured studies are uncertain, unaware, or do not understand chikungunya and/or mosquito borne diseases. This is a potential barrier to community and personal protective actions.

Based on the studies captured in this review, there has been limited research on this subject. By employing the scoping and systematic review methodologies and including studies in multiple languages (English, French, Spanish, and Portuguese), we attempted to identify and include all the relevant research on this topic. However, it is possible that some non-indexed studies or studies in other languages were missed. Many of the identified studies investigated participants' knowledge, perceptions, and attitudes of general mosquito borne diseases rather than chikungunya specifically. Also, in many of the countries where people are at risk of contracting chikungunya, they are also at risk of contracting malaria or dengue, which tend to be more well-known diseases among the general public [18]. This may explain why 
Table 5 Knowledge of the general public on personal protective measures (PPMs)

\begin{tabular}{|c|c|c|c|c|c|c|}
\hline & Author (year) & Location & Sample size & Proportion & Preventative measure & Description of outcome \\
\hline \multicolumn{7}{|c|}{ Mosquito repellents } \\
\hline [21] & Arpit (2012) & India & 274 & $53.3 \%$ & Repellents & $\begin{array}{l}\text { Knowledge on personal control } \\
\text { measures }\end{array}$ \\
\hline [22] & Nagpal (2012) & India & 1000 & $\begin{array}{l}12-52 \% \text { across } \\
\text { study states }\end{array}$ & Repellents & $\begin{array}{l}\text { Knowledge on how to protect } \\
\text { yourself from mosquitoes }\end{array}$ \\
\hline [35] & Majra (2011) & India & $\begin{array}{l}150 \text { cases, } 450 \\
\text { non-cases }\end{array}$ & $\begin{array}{l}72 \% \text { cases } \\
30 \% \text { non-cases }\end{array}$ & Repellents & $\begin{array}{l}\text { Knowledge on preventative } \\
\text { measures }\end{array}$ \\
\hline [31] & Thakor (2015) & India & 100 & $53.3 \%$ & Repellents & Knowledge on personal protection \\
\hline \multicolumn{7}{|c|}{ Mosquito nets } \\
\hline [21] & Arpit (2012) & India & 274 & $71.9 \%$ & Mosquito nets & $\begin{array}{l}\text { Knowledge on personal control } \\
\text { measures }\end{array}$ \\
\hline [22] & Nagpal (2012) & India & 1000 & $\begin{array}{l}0-85 \% \text { across } \\
\text { study states }\end{array}$ & Bed nets & $\begin{array}{l}\text { Knowledge on how to protect } \\
\text { yourself from mosquitoes }\end{array}$ \\
\hline [35] & Majra (2011) & India & $\begin{array}{l}150 \text { cases, } 450 \\
\text { non-cases }\end{array}$ & $\begin{array}{l}60 \% \text { cases } \\
92 \% \text { non-cases }\end{array}$ & Mosquito nets & $\begin{array}{l}\text { Knowledge on preventative } \\
\text { measures }\end{array}$ \\
\hline [31] & Thakor (2015) & India & 100 & $71.9 \%$ & Mosquito nets & Knowledge on personal protection \\
\hline \multicolumn{7}{|c|}{ Mosquito nets and repellents } \\
\hline [19] & Patil (2013) & India & 154 & $23.2 \%$ & Mosquito nets and repellents & $\begin{array}{l}\text { Knowledge on preventing } \\
\text { chikungunya }\end{array}$ \\
\hline \multicolumn{7}{|c|}{ Protective clothing } \\
\hline [22] & Nagpal (2012) & India & 1000 & $\begin{array}{l}1-30 \% \text { across } \\
\text { study states }\end{array}$ & Wear body covering clothing & $\begin{array}{l}\text { Knowledge on how to protect } \\
\text { yourself from mosquitoes }\end{array}$ \\
\hline [35] & Majra (2011) & India & $\begin{array}{l}150 \text { cases, } 450 \\
\text { non-cases }\end{array}$ & $\begin{array}{l}7 \% \text { cases } \\
24 \% \text { non-cases }\end{array}$ & Wearing full dresses & $\begin{array}{l}\text { Knowledge on preventative } \\
\text { measures }\end{array}$ \\
\hline \multicolumn{7}{|c|}{ Mosquito proofing home } \\
\hline [22] & Nagpal (2012) & India & 1000 & $\begin{array}{l}0-6 \% \text { across } \\
\text { study states }\end{array}$ & Make house mosquito proof & $\begin{array}{l}\text { Knowledge on how to protect } \\
\text { yourself from mosquitoes }\end{array}$ \\
\hline$[35]$ & Majra (2011) & India & $\begin{array}{l}150 \text { cases, } 450 \\
\text { non-cases }\end{array}$ & $\begin{array}{l}30 \% \text { cases } \\
70 \% \text { non-cases }\end{array}$ & Screening of houses & $\begin{array}{l}\text { Knowledge on preventative } \\
\text { measures }\end{array}$ \\
\hline \multicolumn{7}{|l|}{ Other } \\
\hline [20] & Kohli (2013) & India & 350 & $5.7 \%$ & Using PPMs & $\begin{array}{l}\text { Knowledge on prevention of } \\
\text { MBDs }\end{array}$ \\
\hline [43] & Raude (2009) & Mayotte & 888 & $60.5 \%$ & Self-protective behavior & $\begin{array}{l}\text { Knowledge of self-protective } \\
\text { behavior }\end{array}$ \\
\hline [18] & Anand (2014) & India & 100 & $93 \%$ & PPMs & $\begin{array}{l}\text { Knowledge on prevention of } \\
\text { MBDs }\end{array}$ \\
\hline$[46]$ & Vaidya (2013) & India & 178 & $74.2 \%$ & Cleaning & $\begin{array}{l}\text { Knowledge on protective } \\
\text { measures }\end{array}$ \\
\hline
\end{tabular}

$M B D$ mosquito borne disease

some populations were knowledgeable on vector control and personal protective measures but have low levels of awareness on chikungunya. Although the disease is endemic in many areas of Africa, Asia, and the Pacific and Indian Ocean Islands, the majority of the studies to date $(43 \%, n=37)$ were conducted in India which has recorded outbreaks of chikungunya for several decades, or La Réunion Island, which experienced a large outbreak in 2005-2006. Based on the geographic distribution of chikungunya, the current studies do not represent all chikungunya-affected populations or even a representative sample. Thus, the knowledge, attitudes, and perceptions of chikungunya-affected populations that are not represented may be different and their absence is a knowledge gap in this review.

The risk of bias assessment and data extraction revealed that the studies captured in this review were not well reported and were missing some critical details. This decreases our confidence in the findings of the studies identified and prevents a reliable interpretation of their results. Across studies, the outcomes reported were not comparable to each other thus preventing synthesis of results or comparisons across populations. Future standardization of outcomes would improve the 
comparability of results across studies making them easier to synthesize and draw more generalizable conclusions about the consistency, direction, and magnitude of the results.

There was a lack of qualitative research on the topic, and it was suggested that there is a need for greater understanding and consideration of varying cultural explanations and for conceptualizations of CHIKV etiology to more effectively address and respond to outbreaks in affected communities [53]. This is supported by some of the beliefs and misunderstandings of respondents in several surveys from this systematic review. The importance of cultural practices and community perception can be critical to the success of epidemic control measures as was the case during the 2014 Ebola outbreak in West Africa [54]. Social stigmatization and deeply ingrained cultural practices such as ritual washing of the deceased and the consumption of bush meat threatened the success of mitigation efforts $[55,56]$. Investigating underlying social factors associated with chikungunya and barriers and facilitators to potential mitigation options through qualitative research would be useful for designing future education and control strategies.

Risk perceptions, attitudes, beliefs, and knowledge are important predictors of an individuals' behavior toward mosquito borne disease $[57,58]$. The relationship between these variables and an individuals' behavior can be explained and predicted by different theories of behavior change, such as the Health Belief Model, Theory of Planned Behavior, and the Stages of Change Model [59]. These theories provide formal and structured frameworks for investigating predictors of health behaviors and for designing health behavior change inventions; however, only nine studies in this review used a formal theory of behavior change to guide their data collection $[22,25,29$, $34,36,40,45,46,60]$. Future studies should use theories of behavior change to investigate the psychosocial risk factors for chikungunya prevention and to design future education and control strategies for CHIKV.

Studies that looked at the general knowledge and perceptions on chikungunya varied across populations and countries. As expected, higher awareness of chikungunya was found in areas affected by an outbreak. This is most likely due to public education, media, and personal experience with the disease. There may also be a difference between recognizing a disease with no depth in knowledge, which is perceived as being informed, compared to factual knowledge about the disease. One study identified literacy, a socio-economic factor that can be considered a surrogate for education and knowledge, as a significant confounder [33]. Other studies found that gender and age were predictors of higher knowledge levels; however, these findings were less consistent and should be investigated further.
Limited studies were conducted on the perceptions of the risk and severity of chikungunya. Two studies that found a high perceived severity of the disease were both conducted on the Indian Ocean Islands [41, 43]. This is to be expected as the studies occurred shortly after the large outbreak in 2005-2006. In contrast, the study in France, where many mosquito borne diseases are not endemic, showed that although the participants recognized the severity of mosquito borne diseases, they were not worried about contracting them [30].

There was a lot of heterogeneity in the level of knowledge on transmission of CHIKV by mosquitoes between studies, likely due to the outbreak status of the area and the amount of public education that had occurred. Knowledge on general mosquito breeding sites was generally higher, which could be attributed in part to the fact that malaria and dengue are endemic in many of these countries and are well-known diseases among the general public. Higher knowledge about vector control and personal protective measures in endemic countries such as India are also likely the result of the presence of many endemic mosquito borne diseases.

The perception of personal control or "self-responsibility" for mitigation was only investigated in a few studies. Since self-efficacy is one of the most important variables in most of the theories of behavior change [59], it would be useful to study perception of control over protection from CHIKV or mosquito borne diseases as a determinant of personal protective behaviors and what education strategies are most likely to empower the individual to participate in proposed mitigation strategies.

This review encompassed knowledge, attitudes, and perceptions of both the general public and health professionals. However, the majority $(86.5 \%, n=37)$ of studies were conducted on the general public. There were no direct comparisons done between the general public and health professionals. Only one outcome, knowledge of CHIKV transmission by mosquitoes, looked at both populations. As expected, health professionals had higher levels of knowledge that mosquitoes transmit CHIKV than the general public. Most of the studies with health professionals measured knowledge of symptoms and perceptions on various treatments. Information from different populations is needed to inform the design of future education and control strategies.

Almost all populations in the studies included in this review were from developing countries with a large proportion of poorly educated individuals that have little to no disposable income. Thus, the affordability of mitigation measures needs to be considered when developing control strategies. For example, although it was shown that insecticides were the most commonly known mitigation strategy, that might not be the best strategy for a community with no disposable income for the insecticides. 


\section{Conclusion}

Overall, this review identified, assessed, and analyzed the global literature on the knowledge, attitudes, and perceptions of CHIKV and its transmission in affected populations. The results indicated that there is variability across populations and countries, but most of the captured populations are uncertain, unaware, or do not understand chikungunya and/or mosquito borne diseases. As the disease continues to spread into previously non-endemic areas, it is recommended that research efforts be increased to close some of the knowledge gaps or better understand the uncertainty identified in this SR with respect to the impact knowledge, attitudes, and perceptions of chikungunya and personal protective measures can have on affected and non-affected populations. Investigations into what motivates individuals to adopt personal protective and vector control measures at home and within their communities will aid in the design and implementation of effective education and control strategies. Researchers in this area are encouraged to follow guidelines on conduct and reporting based on study design to minimize bias in their research and enhance the clarity of their article for use by other researchers and decision makers.

\section{Additional files}

Additional file 1: Protocol for SR of the risk perceptions, attitudes, and/ or knowledge of chikungunya among the public and health professionals (DOCX $73 \mathrm{~kb}$ )

Additional file 2: Citation list of relevant articles (DOCX $41 \mathrm{~kb}$ )

Additional file 3: PRISMA flow diagram of articles through the scoping review process (personal communication M. Mascarenhas 2017) (DOCX 27 kb)

\section{Abbreviations \\ CHIKV: Chikungunya virus; CINAHL: The Cumulative Index to Nursing and Allied Health Literature; LILACS: Latin American and Caribbean Health Sciences Literature; MBD: Mosquito borne disease; PPM: Personal protective measure; PRISMA: Preferred Reporting Items for Systematic Reviews and Meta-Analyses; SR: Systematic review}

\section{Acknowledgements}

Not applicable.

\section{Funding}

This research did not receive any specific grant from funding agencies in the public, commercial, or not-for-profit sectors.

\section{Availability of data and materials}

The datasets used and/or analyzed during the current study are available from the corresponding author on reasonable request.

\section{Authors' contributions}

TC analyzed and interpreted the data. The data was extracted from all studies, and risk of bias was assessed by TC and $\mathrm{CH}$. LW and MM provided extensive feedback and mentorship throughout the project. All authors read, provided feedback, and approved the final manuscript.

Ethics approval and consent to participate Not applicable.

\section{Consent for publication}

Not applicable.

\section{Competing interests}

The authors declare that they have no competing interests.

\section{Publisher's Note}

Springer Nature remains neutral with regard to jurisdictional claims in published maps and institutional affiliations.

\section{Author details}

${ }^{1}$ Public Health Risk Sciences Division, National Microbiology Laboratory, Public Health Agency of Canada, Guelph, ON, Canada. ${ }^{2}$ Department of Population Medicine, University of Guelph, Guelph, ON, Canada. ${ }^{3}$ School of Occupational and Public Health, Ryerson University, Toronto, ON, Canada.

Received: 28 April 2017 Accepted: 15 July 2017

Published online: 04 September 2017

\section{References}

1. Staples EJ, Breiman RF, Powers AM. Chikungunya fever: an epidemiological review of a re-emerging infectious disease. Clin Infect Dis. 2009. doi:10. 1086/605496.

2. Thiberville SD, Moyen N, Dupuis-Maguiraga L, Nougairede A, Gould EA, Rogues $P$, et al. Chikungunya fever: epidemiology, clinical syndrome, pathogenesis and therapy. Antivir Res. 2013. doi:10.1016/j.antiviral.2013.06.009.

3. Centers for Disease Control and Prevention. Chikungunya virus. 2015. https://www.cdc.gov/chikungunya/geo/united-states-2015.html. Accessed 22 July 2016.

4. Weaver SC, Forrester NL. Chikungunya: evolutionary history and recent epidemic spread. Antivir Res. 2015. doi:10.1016/j.antiviral.2015.04.016.

5. European Centre for Disease Control and Prevention. Chikungunya. 2016. https://ecdc.europa.eu/en/chikungunya. Accessed 19 July 2016.

6. Pan American Health Organization. Chikungunya. 2016. http://www.paho. org/hq/index.php?option=com_topics\&view=article\&id=343\&ltemid=40931 Accessed 19 July 2016.

7. Drebot MA, Holloway K, Zheng H, Ogden NH. Travel-related chikungunya cases in Canada, 2014. Canada communicable disease report CCDR. 2015. http://www.phac-aspc.gc.ca/publicat/ccdr-rmtc/15vol41/dr-rm41-01/rapideng.php. Accessed 22 July 2016.

8. World Health Organization. Neglected tropical diseases. 2016. http://www. who.int/neglected_diseases/vector_ecology/NCAG/en/. Accessed 22 July 2016.

9. Henderson LK, Craig JC, Willis NS, Tovey D, Webster AC. How to write a Cochrane systematic review. Nephrology. 2010. doi:10.1111/j.1440-1797. 2010.01380.x.

10. Moher D, Liberati A, Tezlaff J, Altman DG, PRISMA Group. Preferred reporting items for systematic reviews and meta-analyses: the PRISMA statement. Ann Intern Med. 2009;151:264-9.

11. Tranfield D, Denyer D, Smart P. Towards a methodology for developing evidence-informed management knowledge by means of systematic review. Brit J Manage. 2003;14:207-22.

12. Critical Appraisal Skills Programme. 2013. http://www.casp-uk.net/. Accessed 3 Aug 2016.

13. GRADE. 2016. http://www.gradeworkinggroup.org/. Accessed 3 Aug 2016.

14. Lundh A, Gøtzsche PC. Recommendations by Cochrane review groups for assessment of the risk of bias in studies. BMC Med Res Methodol. 2008. doi: 10.1186/1471-2288-8-22.

15. DerSimonian R, Laird N. Meta-analysis in clinical trials. Control Clin Trials. 1986;7:177-88.

16. Higgins JP, Thomson SG, Deeks JJ, Altman DG. Measuring inconsistency in meta-analyses. BMJ. 2003. doi:10.1136/bmj.327.7414.557.

17. Mays N, Pope C, Popay J. Systematically reviewing qualitative and quantitative evidence to inform management and policy-making in the health field. J Health Serv Res Policy. 2005;10(Suppl 1):6-20.

18. Anand T, Kumar R, Saini V, Meena G, Ingle G. Knowledge and use of personal protective measures against mosquito borne diseases in a resettlement Colony of Delhi. Ann Med Health Sci Res. 2014. doi:10.4103/ 2141-9248.129048

19. Patil SS, Patil SR, Durgawale PM, Patil AG. A study of the outbreak of Chikungunya fever. J Clin Diagn Res. 2013. doi:10.7860/JCDR/2013/5330.3061. 
20. Kohli C, Kumar R, Meena GS, Singh MM, Ingle GK. Awareness about mosquito borne diseases in rural and urban areas of Delhi. J Commun Disord. 2013;45:201-7.

21. Arpit $P$, Sonal $P$, Manish F, DV B. Impact of educational intervention regarding mosquito borne diseases and their control measures among the link Workers of Urban Health Centers (UHCs) of Ahmedabad City. Natl J Community Med. 2012;3:178-82.

22. Nagpal BN, Saxena R, Srivastava A, Singh N, Ghosh SK, Sharma SK, et al. Retrospective study of chikungunya outbreak in urban areas of India. Indian J Med Res. 2012;135:351-8.

23. Ghosh SK, Chakaravarthy P, Panch SR, Krishnappa P, Tiwari S, Ojha VP, et al. Comparative efficacy of two poeciliid fish in indoor cement tanks against chikungunya vector Aedes Aegypti in villages in Karnataka. India BMC Public Health. 2011. doi:10.1186/1471-2458-11-599.

24. Surendran SN, Kannathasan S, Kajatheepan A, Jude PJ. Chikungunya-type fever outbreak: some aspects related to this new epidemic in Jaffna district, northern Sri Lanka. Trop Med Health. 2007:35:249-52.

25. Cherry CC, Beer KD, Fulton C, Wong D, Buttke D, Staples JE, et al. Knowledge and use of prevention measures for chikungunya virus among visitors--Virgin Islands National Park, 2015. Travel Med Infect Dis. 2016. doi: 10.1016/j.tmaid.2016.08.011.

26. Millman AJ, Esposito DH, Biggs HM, Decenteceo M, Klevos A, Hunsperger $E_{\text {, }}$ et al. Chikungunya and dengue virus infections among United States community service volunteers returning from the Dominican Republic, 2014. Am J Trop Med Hyg. 2016. doi:10.4269/ajtmh.15-0815.

27. Kuan G, Ramirez S, Gresh L, Ojeda S, Melendez M, Sanchez N, et al. Seroprevalence of anti-Chikungunya virus antibodies in children and adults in Managua, Nicaragua, after the first Chikungunya epidemic, 2014-2015. PLoS Negl Trop Dis. 2016. doi:10.1371/journal.pntd.0004773.

28. Doke PP, Dakhure DS, Patil AV. A clinico-epidemiological study of chikungunya outbreak in Maharashtra state. India Indian J Public Health. 2011. doi:10.4103/0019-557X.92413.

29. Fritzell C, Raude J, Adde A, Dusfour I, Quenel P, Flamand C. Knowledge, attitude and practices of vector-borne disease prevention during the emergence of a new Arbovirus: implications for the control of Chikungunya virus in French Guiana. PLoS Negl Trop Dis. 2016. doi:10.1371/journal.pntd.0005081.

30. Raude J, Chinfatt K, Huang P, Betansedi CO, Katumba K, Vernazza N, et al. Public perceptions and behaviours related to the risk of infection with Aedes mosquito-borne diseases: a cross-sectional study in southeastern France. BMJ Open. 2012. doi:10.1136/bmjopen-2012-002094.

31. Thakor NC, Vikani SK, Nagar AA. Impact of educational intervention regarding mosquito-borne diseases and their control measures among multipurpose health workers (MPHWs) of Patan district, Gujarat, India. Int J Med Sci Public Health. 2015;4:1620-3.

32. Mehta D, Solanki H, Patel P, Umat P, Chauhan R, Shukla S, et al. A study on knowledge, attitude \& practice regarding mosquito borne diseases in an urban area of Bhavnagar. Health. 2015;6:29-32.

33. Boratne AV, Jayanthi V, Datta SS, Singh Z, Senthilvel V, Joice YS. Predictors of knowledge of selected mosquito-borne diseases among adults of selected peri-urban areas of Puducherry. J Vector Borne Dis. 2010;47:249-56.

34. Bedoya-Arias JE, Murillo-García DR, Bolaños-Muñoz E, Hurtado-Hurtado N, Ramírez-Jaramillo V, Granados-Álvarez S, et al. Healthcare students and workers' knowledge about epidemiology and symptoms of chikungunya fever in two cities in Colombia. J Infect Dev Ctries. 2015. doi:10.3855/jidc.6445.

35. Majra JP, Acharya D. Impact of knowledge and practices on prevention of chikungunya in an epidemic area in India. Ann Trop Med PH. 2011;4:3-6.

36. Tenglikar PV, Hussain M, Nigudgi SR, Ghooli S. Knowledge and practices regarding mosquito borne disease among people of an urban area in Kalaburgi, Karnataka. Natl J Community Med. 2016;7:223-5.

37. Claeys C, Robles C, Bertaudiere-Montes V, Deschamps-Cottin M, Megnifo HT, Pelagie-Moutenda $\mathrm{R}$, et al. Socio-ecological factors contributing to the exposure of human populations to mosquito bites that transmit dengue fever, chikungunya and zika viruses: a comparison between mainland France and the French Antilles. Environ Risque Sante. 2016;15:318-25.

38. Hsu LY, Jin J, Ang BS, Kurup A, Tambyah PA. Hand hygiene and infection control survey pre- and peri-H1N1-2009 pandemic: knowledge and perceptions of final year medical students in Singapore. Signapore Med J. 2011;52:486-90.

39. Dilip C, Saraswathi R, Krishnan PN, Azeem AK, Raseena A, Ramya JJ. Comparative evaluation of different systems of medicines and the present scenario of chikungunya in Kerala. Asian Pac J Trop Med. 2010. doi:10.1016/ S1995-7645(10)60106-X.
40. Moro ML, Gagliotti C, Silvi G, Angelini R, Sambri V, Rezza G. Knowledge, attitudes and practices survey after an outbreak of chikungunya infections. Int Health. 2010. doi:10.1016/j.inhe.2010.07.003.

41. Setbon M, Raude J. Chikungunya on Réunion Island: social, environmental and Behavioural factors in an epidemic context. Population. 2008. doi:10. 3917/popu.803.0555.

42. Thuilliez J, Bellia C, Dehecg JS, Reilhes O. Household-level expenditure on protective measures against mosquitoes on the island of La Reunion. France PLoS Negl Trop Dis. 2014. doi:10.1371/journal.pntd.0002609.

43. Raude J, Setbon M. The role of environmental and individual factors in the social epidemiology of chikungunya disease on Mayotte Island. Health Place. 2009. doi:10.1016/j.healthplace.2008.10.009.

44. Adalja A, Sell TK, McGinty M, Boddie C. Genetically modified (GM) mosquito use to reduce mosquito-transmitted disease in the US: a community opinion survey. PLoS Curr. 2016. doi:10.1371/currents.outbreaks.

45. Aswathy S, Dinesh S, Kurien B, Johnson AJ, Leelamoni K. A post-epidemic study on awareness of vector habits of Chikungunya and vector indices in a rural area of Kerala. J Commun Disord. 2011;43:209-15.

46. Vaidya V, Sawant S. A KAP study in Pune City involving school children as a strategy for effective vector control in Chikungunya. Indian J Public Health. 2013. doi:10.5958/j.0976-5506.4.4.181.

47. Puwar T, Sheth JK, Kohli V, Yadav R. Prevalence of chikungunya in the city of Ahmedabad, India, during the 2006 outbreak. WHO Dengue Bulletin. 2010. http://apps.who.int/iris/bitstream/10665/170980/1/db2010v34p40.pdf. Accessed 7 June 2016.

48. Flahault A, Aumont $G$, Boisson V, de Lamballerie X, Favier F, Fontenille $D$, et al. An interdisciplinary approach to controlling chikungunya outbreaks on french islands in the south-west indian ocean. Med Trop (Mars). 2012;72:66-71.

49. Goorah S, Dewkurun MK, Ramchurn SK. Assessing the sustainability of individual behavior change against mosquitos after the outbreak of a vector-borne disease in Mauritius: a case study. IJMU. 2013:8:9-16.

50. Jansen KA. The 2005-2007 Chikungunya epidemic in Reunion: ambiguous etiologies, memories, and meaning-making. Med Anthropol. 2013; doi:10. 1080/01459740.2012.679981

51. Abramides GC, Roiz D, Guitart R, Quintana S, Giménez N. Control of the Asian tiger mosquito (Aedes Albopictus) in a firmly established area in Spain: risk factors and people's involvement. Trans R Soc Trop Med Hyg. 2013; doi:10.1093/trstmh/trt093.

52. Fenétrier E, Sissoko D, Vernazza-Licht N, Bley D, Gaüzère BA, Malvy D. Feedback from primary care practitioners two years after the chikungunya epidemic on Reunion. Bull Soc Pathol Exot. 2013; doi:10.1007/s13149-013-0295-8.

53. Jansen KA. The printed press's representations of the 2005-2007 chikungunya epidemic Réunion: political polemics and (post)colonial disease. J Afr Media Stud. 2012:4:227-42.

54. Scott V, Crawford-Browne S, Sanders D. Critiquing the response to the Ebola epidemic through a Primary Health Care Approach. BMC Public Health. doi: 10.1186/s12889-016-3071-4.

55. Alexander KA, Sanderson CE, Marathe M, Lewis BL, Rivers CM, Shaman J, et al. What factors might have led to the emergence of Ebola in West Africa? PLoS Negl Trop Dis. 2015; doi:10.1371/journal.pntd.0003652

56. Phua KL. Meeting the challenge of Ebola virus disease in a holistic manner by taking into account socioeconomic and cultural factors: the experience of West Africa. Infect Dis (Auckl). 2015; doi:10.4137/IDRT.S31568.

57. Beaujean DJMA, Bults M, van Steenbergen JE, Voeten HACM. Study on public perceptions and protective behaviors regarding Lyme disease among the general public in the Netherlands: implications for prevention programs. BMC Public Health. 2013; doi:10.1186/1471-2458-13-225.

58. Trumbo CW, Harper R. Perceptual influences on self-protective behavior for West Nile virus, a survey in Colorado. USA BMC Public Health. 2015; doi:10. 1186/s12889-015-1918-8

59. Edberg MC. Essentials of health behaviour. Burlington: Social and Behavioural Theory in Public Health. Jones and Bartlett Publishers, Inc; 2007.

60. Vilain P, Larrieu S, Renault P, Baville M, Filleul L. How to explain the reemergence of chikungunya infection in Reunion Island in 2010? Acta Trop. 2012. doi:10.1016/j.actatropica.2012.03.009

61. Boyer S, Foray C, Dehecq JS. Spatial and temporal heterogeneities of Aedes albopictus density in La Reunion Island: rise and weakness of entomological indices. PLoS One. 2014. doi:10.1371/journal.pone.0091170. 